\title{
Parental diuron-exposure alters offspring transcriptome and fitness in Pacific oyster Crassostrea gigas
}

\author{
Bachère Evelyne ${ }^{1,}{ }^{*}$, Barranger Audrey ${ }^{2}$, Bruno Roman ${ }^{3}$, Rouxel Julien ${ }^{2}$, Menard Dominique ${ }^{2}$, \\ Piquemal David ${ }^{3,4}$, Akcha Farida ${ }^{2}$
}

1 Univ Montpellier, IFREMER, CNRS,UMR 5244, IHPE Interact Hosts Pathogens Environm,UPVD,CC 80, F-34095 Montpellier, France.

2 IFREMER, Lab Ecotoxicol, Rue lle Yeu,BP21105, F-44311 Nantes 03, France.

${ }^{3}$ Acobiom, 1682 Rue Valsiere, F-34184 Montpellier 04, France.

${ }_{4}^{4}$ Diag4Zoo, 1 Rue Loutres, F-34170 Montpellier, France.

* Corresponding author : Evelyne Bachère, email address : ebachere@ifremer.fr

\begin{abstract}
:
One of the primary challenges in ecotoxicology is to contribute to the assessment of the ecological status of ecosystems. In this study, we used Pacific oyster Crassostrea gigas to explore the effects of a parental exposure to diuron, a herbicide frequently detected in marine coastal environments. The present toxicogenomic study provides evidence that exposure of oyster genitors to diuron during gametogenesis results in changes in offspring, namely, transcriptomic profile alterations, increased global DNA methylation levels and reduced growth and survival within the first year of life. Importantly, we highlighted the limitations to identify particular genes or gene expression signatures that could serve as biomarkers for parental herbicide-exposure and further for multigenerational and transgenerational effects of specific chemical stressors. By analyzing samples from two independent experiments, we demonstrated that, due to complex confounding effects with both tested solvent vehicles, diuron non-specifically affected the offspring transcriptome. These original results question the potential development of predictive genomic tools for detecting specific indirect impacts of contaminants in environmental risk assessments. However, our results indicate that chronic environmental exposure to diuron over several generations may have significant long term impacts on oyster populations with adverse health outcomes.
\end{abstract}




\section{Graphical abstract}

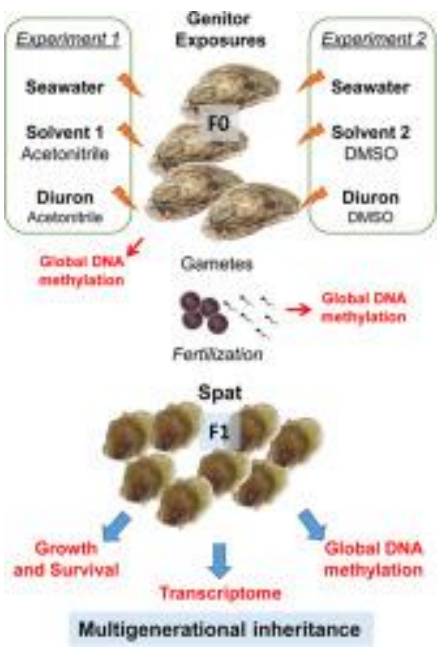

\section{Highlights}

- Effects of parental diuron exposure were evidenced in an exploited marine bivalve. Growth and survival rates of offspring were transiently affected. Global DNA methylation levels were increased in genitor sperm and in offspring. - Great alterations occurred in transcriptomic profiles. Diuron impact was not gene-specific due to confounding effects with solvents used.

Keywords : Marine bivalve, Herbicide, Toxicogenomics, Survival, Biomarkers, Global DNA-methylation 


\section{Introduction}

Genome-wide approaches are now increasingly used in attempts to unravel the molecular responses to specific environmental pollutants and to develop genomic tools and biomarkers for further prediction of the long-term effects of chronic exposure on wild populations (Bahamonde et al., 2016). Indeed, transcriptional modulations or changes in gene expression patterns may reveal various genome alterations that can be inherited, even when the triggering factor is absent. Such genome changes within individuals can affect fitness and modify the population adaptive capacity to environmental stress, further increasing physiological dysfunctions and disease risks.

Since decades, mass mortalities in marine invertebrates are regularly observed worldwide in coastal environments that are particularly subjected to anthropogenic pressures and/or extreme environmental conditions (Harvell, 1999; Rivetti et al., 2014). One striking ecological crisis concerns the oyster Crassostrea gigas, a mollusk species that is cultivated in estuarine zones and lagoons. Whereas it is now recognized that these mortalities have multifactorial origins, including temperature-dependent polymicrobial diseases and oyster genetic background (Segarra et al., 2014; Petton et al., 2015), chemical pollution must be considered as a potential risk factor for oyster health. Indeed, the mass mortalities observed today may reveal physiological weakness and changes in adaptive capacity, increasing the susceptibility of this oyster species to infectious diseases.

Among the priority chemicals to monitor in coastal environments (45 dangerous substances identified by the European Water Framework Directive-2013/39/UE), we have focused on diuron (3-[3,4-dichlorophenyl]-1,1dimethylurea), a herbicide that is still detected at high concentrations in oyster culture zones despite its restricted use in France since 2008 (Giacomazzi and Cochet, 2004; Caquet et al., 2013). In recent studies, we have demonstrated the molecular impact of diuron on C. gigas. Using a transcriptional approach, we showed that exposure of oyster genitors to diuron at environmental concentrations affected the expression of genes with functions known to play a major role during gametogenesis, such as gene transcriptional regulation, DNA replication and repair, DNA methylation and cytokinesis (Akcha et al., 2016). Additionally, a genotoxic effect has been detected based on evidence for primary DNA damage in both somatic, germinal and reproductive cells of diuron-exposed genitors, and chromosomal abnormalities in their offspring (DNA aneuploidy) (Barranger et al., 2014, 2015).

In the present study, we provide evidence for the effects of a parental diuron-exposure on C. gigas spat at both transcriptional and epigenetic levels. We considered, for the first time, whether the parental herbicide exposure could induce specific changes in the expression profiles of targeted genes or may operate non-specifically in the transcriptome, which is a question to address for further developing transcriptomic markers for environmental biomonitoring of pollutant-exposure effects. By analyzing two independent experiments, we evidenced complex confounding effects of diuron and its solvent vehicles at the transcriptomic level, which interfered with the potential characterization of a diuron-specific signature. Finally, besides alterations in transcriptome and global DNA mehylation levels, we showed also that parental diuron-exposures resulted in transient effects on oyster fitness such as reduced survival capacity and growth.

\section{Materials and methods}

\subsection{Experimental diuron exposure of oyster genitors and production of offspring}

The analyzed spat were progenies issued from experimental exposures of Pacific oyster Crassostrea gigas genitors to diuron during gametogenesis. All chemicals used in the experimental exposures were purchased from Sigma Aldrich Chemicals (France). 
Experiment 1 (Exp1) is detailed in Barranger et al. (2014). Briefly, adult oysters (720 individuals) were divided into three experimental groups: a diuron-exposed group (D), a solvent-exposed group (S1) and a seawater control group (SW). In Exp1, diuron (Pestanal, analytical standard) was prepared in $0.005 \%$ acetonitrile solvent (anhydrous, 99.8\%). At the start and middle of gametogenesis, the oysters were exposed for two 7-day exposure periods to pulses of 0.2 and $0.3 \mu \mathrm{g} / \mathrm{L}$ of diuron, respectively, and of $0.005 \%(50 \mu \mathrm{L} / \mathrm{L})$ acetonitrile for the $\mathrm{S} 1$ group. These values corresponded to environmentally realistic concentrations of diuron detected in coastal waters (Barranger et al., 2014).

Experiment 2 (Exp2) was performed according to the same procedure described in Exp1 but with some modifications. Genitors (180 individuals per group) were the progenies of the SW control group from Exp1 thus displaying a common genetic background. The main difference was that dimethyl sulfoxide (DMSO) at a final concentration of $0.005 \%$ replaced acetonitrile as the solvent vehicle. Moreover, genitors were exposed to two 7-day exposure pulses at the start and mid-course of gametogenesis, followed by an additional 4-day final pulse at the end of gonad maturation. Besides the seawater control group (SW), the oysters were exposed during this second experiment to

$0.005 \%$ DMSO in seawater (S2) and to a higher concentration of $0.48 \pm 0.02 \mu \mathrm{g} / \mathrm{L}$ of diuron in $0.005 \%$ DMSO (D) as confirmed by the use of Polar Organic Chemical Integrative Samplers (POCIS) in the tanks. This increased extent to diuron exposure in terms of both duration and concentration aimed at exacerbating the toxic response and confirming the toxicity of diuron previously demonstrated (Barranger et al., 2014).

In both experiments, following the last pulse, oysters from each group were grown to maturity and underwent fertilization and production of the next spat generation as previously described (Barranger et al., 2014).

\subsection{Follow-up of spat growth and survival capacity}

In Exp1, spat growth (total weight, length and width of the shell) was followed at the hatchery for each group at 3, 6,8 and 20 months ( $n=60$ animals per group). To determine survival rate in the field, 8month spat from each exposure group were deployed from December 2012 to August 2013 at two sites, La Floride $\left(1^{\circ} 10^{\prime} \mathrm{W}, 45^{\circ} 48^{\prime} \mathrm{N}\right)$ and Agnas $\left(1^{\circ} 10^{\prime} \mathrm{W}, 45^{\circ} 52^{\prime} \mathrm{N}\right)$, located in Marennes-Oléron Bay, one of the two main harnessing oyster basins in France (Soler, 2014). Both sites have experienced recurrent massive mortality outbreaks of C. gigas, with La Floride being particularly exposed to potential pollution from inland activities. Spat were cultured following usual off-bottom local practices. Mortalities were recorded from May to August 2013 during the field mortality period.

In Exp2, spat growth was measured at the hatchery until the spat reached 5 months old ( $\mathrm{n}=40$ animals per group). Survival rates in the field were monitored at two contrasting sites in terms of culture practices, environmental conditions and mortality outbreaks. Spat were cultured from October 2014 (7 months old) to September 2015 in Thau Lagoon (Mediterranean coast), and from November 2014 (8 months old) to October 2015 in Bourgneuf Bay (Atlantic coast).

\subsection{Genome-wide transcription analyses}

Oyster spat ( 5 months old; $10 \mathrm{mg}$ ) from each exposure group and experiment ( $\mathrm{n}=30$ individuals per group) were sampled and immediately frozen in liquid nitrogen for further RNA extraction. RNA was isolated from individual whole bodies using the NucleoSpin 96 RNA Tissue Core kit from Macherey Nagel. Briefly, frozen spat were first homogenized in $1 \mathrm{~mL}$ of RL1 lysis buffer, supplied with the kit, with 1\% $\beta$-mercaptoethanol (twice: $2 \mathrm{~min}, 30$ oscillations/s in a Mixer Mill MM 400 Retsch) before proceeding to RNA extraction according to the manufacturer's instructions. Total RNA quantity and quality were checked using NanoDrop ND-1000 spectrophotometer (Thermo Fisher

Scientific). 
For the RNAseq analyses, total RNA from 10 spat from Exp1 was pooled in equal quantities to provide templates ( 5 $\mu \mathrm{g})$ for each cDNA library. Two libraries per oyster group (D, S1 and SW) were constructed as biological duplicates. The Illumina TruSeq ${ }^{\mathrm{TM}}$ RNA sample preparation V2 kit (low-throughput protocol) was used according to the manufacturer's instructions. Briefly, $5 \mu \mathrm{g}$ of total RNA was used for two rounds of poly-A mRNA enrichment using streptavidin-coated magnetic beads. The purified mRNA was then fragmented for 8 min at $94{ }^{\circ} \mathrm{C}$, yielding fragments of 120-210 bp with a median insert length of $155 \mathrm{bp}$. The fragmented mRNA samples were subjected to cDNA synthesis using reverse transcriptase (SuperScript II) and random primers. The cDNA was further converted into double-stranded DNA using the reagents supplied with the kit. The dsDNA was further subjected to end repair, Atailing, and adapter ligation in accordance with the manufacturer's protocol. Purified dsDNA was then enriched via 15 cycles of PCR. Purified cDNA libraries were quantified using the Bioanalyzer DNA 1000 Chip. The libraries were normalized by real-time PCR and then multiplexed randomly two-by-two for cluster generation. Sequencing was performed in 3 lanes of the Illumina HiSeq. 2000 by Eurofins Genomics France. Fastq reads are available under BioProjects accession number PRJNA291364 at the NCBI SRA. RNAseq analyses were performed using the set of open source software programs in the Tuxedo suite, TopHat (v2.0.5) and Cufflinks (v2.0.2), as described by (Trapnell et al., 2012). TopHat is designed to align RNAseq reads to a reference genome, whereas Cufflinks assembles these mapped reads into possible transcripts and then generates a final transcriptome assembly. Cufflinks also includes Cuffdiff, which accepts the reads assembled from two or more biological conditions and analyzes their differential expression of genes and transcripts, allowing the investigation of their transcriptional and post-transcriptional regulation under different conditions. An accessory tool called CummeRbund was then used to complete the statistical analysis, which processes the output files of Cuffdiff and provides an output of publication quality plots and figures of the user's choice. Loci identified as differentially expressed were further explored using the Integrative Genomics Viewer (IGV) (Thorvaldsdóttir et al., 2013) for visualization of exon expression across the 6 libraries and further for primer design. The data have been mapped to the available oyster reference genome, CgigasV9 (Zhang et al., 2012).

\subsection{High-throughput microfluidic qPCR Biomark ${ }^{T M}$ (Fluidigm)}

For the high-throughput qPCR analyses, cDNAs were synthesized from $300 \mathrm{ng}$ of total individual RNA samples using VILO Superscript enzyme (Invitrogen) and pre-amplified using the TaqMan PreAmp kit (Applied Biosystems). The relative gene expression of selected 96 genes was analyzed in triplicate for 90 individuals (30 from each exposure group) using the microfluidic qPCR platform Biomark ${ }^{\mathrm{TM}}$ (Fluidigm) (Jang et al., 2011). The pre-amplification cycling program consisted of 14 cycles $\left(95^{\circ} \mathrm{C} / 15 \mathrm{~s}\right.$ and $\left.60^{\circ} \mathrm{C} / 4 \mathrm{~min}\right)$. The amplification cycling program consisted of $35 \mathrm{cycles}$ $\left(95^{\circ} \mathrm{C} / 15 \mathrm{~s}\right.$ and $\left.60^{\circ} \mathrm{C} / 60 \mathrm{~s}\right)$. Melting curve analyses were performed after collecting the qPCR fluorescence between 60 and $95^{\circ} \mathrm{C}$ in $0.5^{\circ} \mathrm{C}$ increments. The qPCR data were analyzed using the Biomark ${ }^{\mathrm{TM}} \mathrm{qPCR}$ analysis software (Fluidigm). The relative expression was normalized according to the $2^{\Delta \Delta C q}$ method (Livak and Schmittgen, 2001) with the Cq geometric mean value of the eukaryotic translation elongation factor 1-alpha (Cg-ef1 $\alpha$ : AB122066), the ribosomal protein L40 (Cg-rpl40: FP004478) and the 40 S ribosomal protein S6 (Cg-rps6: CU686508) as endogenous reference genes (Rosa et al., 2012).

\subsection{Global DNA methylation level}

For Exp1, the global DNA methylation level was measured in genitors (4 individuals per group) at T0 and at the end of the last exposure pulse, and in 5-month-old offspring 19-21 individuals per groups). Considering the results obtained in Exp1, measures were performed in both genitor sperm (5 individuals per group) and offspring 14-16 individuals per exposure group) in Exp2. Genomic DNA (gDNA) was isolated from the same individuals used for 
transcriptomics. Frozen whole oyster bodies and sperm were incubated overnight at $55^{\circ} \mathrm{C}$ in $500 \mu \mathrm{L}$ of DNA extraction buffer (0.1 M Tris- $\mathrm{HCl}$ pH 8.5, $0.1 \mathrm{M} \mathrm{NaCl}, 0.05 \mathrm{M} \mathrm{EDTA} \mathrm{pH} \mathrm{7,} \mathrm{1 \%} \mathrm{SDS,} \mathrm{proteinase} \mathrm{K}$ at $5 \mu \mathrm{g} / \mathrm{mg}$ of tissue). Following a 30-min extraction step with $200 \mu \mathrm{L}$ of $3 \mathrm{M}$ potassium acetate, the gDNA samples were precipitated overnight at -20 ${ }^{\circ} \mathrm{C}$ by addition of $250 \mu \mathrm{L}$ of isopropanol. The quantity and quality of the gDNA samples were assessed by spectrophotometry (NanoDrop ND1000 Thermo Scientific). The global DNA methylation level was analyzed by HPLC according to Armstrong et al. (2011) with some modifications. For each sample, gDNA samples ( 2 up to $5 \mu \mathrm{g}$ ) were digested with nuclease $\mathrm{P} 1(1.5 \mathrm{U} / \mu \mathrm{g} \mathrm{DNA})$ for $2 \mathrm{~h}$ at $37^{\circ} \mathrm{C}$, and then alkaline phosphatase $(2.5 \mathrm{U} / \mu \mathrm{g}$ DNA) was added for $1 \mathrm{~h}$ at $37{ }^{\circ} \mathrm{C}$. After centrifugation $\left(10 \mathrm{~min}, 7000 \times \mathrm{g}, 4^{\circ} \mathrm{C}\right.$ ), the supernatants were analyzed by HPLC coupled to UV detection (Agilent 1200 series). The deoxyribonucleosides were separated at $10^{\circ} \mathrm{C}$ on a Phenomenex Security Guard ULTRA Cartridges UHPLC C18 pre-column and a Phenomenex

Kinetex 2.6 $\mu \mathrm{m} \mathrm{C18} 100 \mathrm{~A} 100 \times 4.6 \mathrm{~mm}$ column. The mobile phase was $50 \mathrm{mM}$ diammonium hydrogen orthophosphate (diammonium hydrogenophosphate), $3 \%$ acetonitrile, $\mathrm{pH} 4.1$ using the isocratic mode. The elution flow rate was set at $1.3 \mathrm{~mL} / \mathrm{min}$, and the pressure in the system was 330 bars. Commercially available nucleotides (dAMP, dTMP, dGMP, $\mathrm{dCMP}, \mathrm{dUMP}$ ) were injected individually and in a mixture (total injection volume of $13 \mu \mathrm{L}$ ) to determine their respective retention time following UV detection at $280 \mathrm{~nm}$. Standard curves were also generated for dCMP (0.5-2.0 nmoles) and 5-mdCMP (0.015-0.100 nmoles) to calculate the \% methylation for each sample using the following equation: \% 5-mdCMP $=[5-\mathrm{mdCMP} /(\mathrm{dCMP}+5-\mathrm{mdCMP})] \times 100$. For the described conditions, the run time was $10 \mathrm{~min}$ and the retention times for both $\mathrm{dCMP}$ and 5-mdCMP were 1.4 and $2.2 \mathrm{~min}$, respectively.

\subsection{Statistical analyses}

Statistical analyses were performed using STATISTICA software (StatSoft, Inc. Version 10). For the growth and methylation data, the homogeneity of variance was evaluated by Bartlett's test, and differences between treatments were tested by analysis of variance (ANOVA). When differences between groups were significant $(p<0.05)$, the posthoc Tukey test was applied. When the homogeneity of variance assumption was rejected, the nonparametric Kruskal-Wallis test was performed. The non-parametric Kaplan-Meier test was used to estimate log-rank and Wilcoxon values for comparing the survival performance of the spat.

For gene expression, analyses were performed with the R software (v3. 1 64bits) and the ddCt package (v1.18.0). The Mann-Whitney pairwise comparison test was used to determine significant differences in the relative expression of each gene between the three spat groups. For the identification of highly specific marker genes, we considered more stringent significant differences considering a $\mathrm{p}$ value $<0.025$ after Bonferroni correction.

\section{Results}

\subsection{Parental exposure affects the offspring transcriptome: identification of genes specifically targeted by parental diuron-exposure in Exp1}

First, the RNAseq approach was performed for the pre-discovery of sequences that were differentially expressed between the three oyster spat groups issued, respectively, from parental exposure to diuron (D), solvent acetonitrile (S1) and from seawater (SW) in Exp1. Briefly, two libraries per oyster group (D, S1 and SW) were constructed as biological duplicates and sequenced ( $1 \times 100$ bp). Up to 1555 million reads were obtained ( 105 million reads per library), and cleaned sequences were aligned to the reference genome CgigasV9 (11,969 sequences). A total of 4505 reads were assigned (Table S1). Using CuffDiff, we performed a comparison with the built-in CuffDiff statistic to test 
the three conditions based on the FKPM derived from counting. For a high level of stringency, we chose the strategy of adjusting our type 1 error $(\alpha=0.05)$ with a Bonferroni correction with three hypotheses for each condition that resulted in ( $\alpha$ corrected=0.016). We obtained a list of 62 loci and 70 potential targeted genes (8 loci were associated with 2 distinct genes) that were differentially regulated between all three conditions (Table S2).

To assess the impact of parental diuron exposure at the transcriptional level, we explored the expression profiles of the selected genes by high-throughput microfluidic qPCR in 30 individuals (5-months old) from the D, S1 and SW groups in Exp1. A total of 96 genes were chosen, including (i) 70 genes identified in the RNAseq approach as differentially expressed (GMP01 to GMP70) and three genes displaying no differential expression (GMPREF01 to -03) and (ii) 20 genes identified in a previous study as differentially expressed according to the oyster capacity to survive infections and three endogenous reference genes (Rosa et al., 2012). The list of selected genes, their GenBank identifiers and primer sequences are given in Table S2. Primer pair qPCR efficiencies are given in Table S3. The technical efficiency of the qPCR analyses was controlled by measuring the expression of these three reference genes on each qPCR chip with obtained M-values (gene stability measures, (Vandesompele et al., 2002) of 0.068, 0.066 and 0.067 , respectively.

There were no significant differences in the expression profiles of the RNAseq reference genes, GMPREF01 to GMPREF03, and the endogenous reference genes among the three oyster groups (,$S 1$ and SW). Analysis of the large qPCR data set revealed that $61.5 \%$ of the genes were differentially expressed $(p<0.05)$ between groups. Great oyster inter-individual variability was observed for most of the target genes analyzed (Fig. S1), with extreme case of absence of gene expression in some individuals as already reported in previous transcriptomic studies in oyster (Rosa et al., 2012). This phenomenon concerned 10 genes for which the basal expression level could not be detected in at least one of the thirty oysters analyzed per group (Table S4). Additionally, striking diversity in gene expression profiles was also observed (Fig. S1). The number of genes affected by the different parental exposure conditions is depicted in the Venn diagram (Fig. 1A). Parental diuron-exposure has specifically deregulated 18 genes (16 genes exhibiting overexpression and 2 underexpression) whereas acetonitrile-exposure has specifically affected 15 genes (3 being overexpressed and 12 underexpressed). It is noteworthy that the specific effect of parental diuron-exposure was mainly reflected in a gene upregulation, whereas the effect of acetonitrile was reflected in a downregulation of genes (Fig. 1A; Fig. S1). Besides, the diversity of expression profiles suggested also complex interaction effects of diuron and its solvent vehicle during parental exposure (Fig. S1). The Venn diagram shows additive effects for 8 underexpressed genes and 4 overexpressed genes whereas antagonist effects concerned 11 genes (Fig. 1A).

To strengthen the identification of specific gene markers for the effect of parental exposure, a $p$ value of 0.025 (after Bonferroni correction) was used in a second step. Thus, 11 genes were identified as specific markers for diuronexposure, and 6 genes were specific for acetonitrile-exposure (Table S5; Fig. S1). The specific effects of parental diuron-exposure are illustrated in Fig. 2A with the genes GMP04 (hypothetical protein; EKC30829), GMP12 (rabenosyn-5; EKC20228) or GMP67 (ADP-ribosylation factor-like protein 13B; EKC19515). The specific effects of acetonitrile-exposure are illustrated by GMP30 (fibrinogen C domain-containing protein1; EKC25528), GMP37 (natterin4; EKC18181) or GMP46 (hypothetical protein; EKC22588) (Fig. 2A). Antagonist effects of diuron and acetonitrile following parental exposure are illustrated by the GMP40 gene (Hypothetical protein; EKC17591; Table S2) and more strikingly by GMP45 (EKC22676) encoding a signal peptide, CUB and EGF-like domain-containing protein3. This gene was found to be a marker for both types of exposure, exhibiting upregulated profiles in the diuron group and downregulated profiles in the solvent group, respectively (Fig. 2A).

\subsection{The effect of parental diuron-exposure on offspring transcriptome is not gene-specific}


To explore the specificity of the parental diuron-exposure effect on the offspring transcriptome, we analyzed the expression of the same set of target genes in 5-month-old spat produced in the frame of another exposure experiment (Exp2). In Exp2, acetonitrile was replaced with $0.005 \%$ DMSO as solvent vehicle for diuron and exposure to the herbicide was increased in terms of both duration and concentration $(0.48 \mu \mathrm{g} / \mathrm{L}$ instead of $0.3 \mu \mathrm{g} / \mathrm{L})$ to exacerbate the toxic response previously observed in Exp1 (Barranger et al., 2014). Based on the qPCR data set, up to 54 genes appeared to be affected by the absence of expression in at least one individual among the thirty ones analyzed per group (Table S4). Significant differences in gene expression levels $(p<0.05)$ between spat groups were observed for $51.8 \%$ of the genes (Fig. S2). The number of genes affected in the different exposure conditions greatly differed from that observed in Exp1 (Fig. 1B). The effect of parental diuron-exposure was characterized in offspring by the upregulation of only 2 genes and downregulation of 9 genes, whereas the effect of DMSO-exposure was characterized by the upregulation of 10 genes and the downregulation of 3 genes (Fig. 1B). Additive effects between diuron and DMSO were seen for 6 genes and antagonist effects for 11 genes (Fig. 1B). It is noteworthy that, in Exp2 unlike Exp1, the specific effect of parental diuron-exposure was mainly reflected in a gene underexpression and the effect of the solvent vehicle in an overexpression.

According to Bonferroni statistical criteria $(p<0.025)$, we obtained 5 gene markers for the specific effect of parental diuron-exposure as compared with 11 in Exp1 (Table S5; Fig. S2). For example, GMP12 and GMP67 were common markers to both experiments but with opposite expression patterns, namely a downregulation in Exp2 compared with an upregulation in Exp1 (Fig. 2B). Regarding the specific effect of DMSO, 9 marker genes were identified (Table S5), including GMP04, which was identified in Exp1 as a specific marker for diuron parentalexposure, and GMP37, which was overexpressed in Exp2 and underexpressed in Exp1 (Fig. 2B). It is noteworthy that the expression of the GMP45 gene, a marker for the antagonistic effect of diuron and acetonitrile in Exp1, was affected in Exp2 only following parental DMSO-exposure (Fig. 2B).

Based on the results obtained in the two exposure experiments, the effect of parental diuron-exposure appeared to be not specific in terms of the involved target genes and no specific transcriptional signature was identified. Rather, the effect of diuron appeared to be dependent on the solvent vehicle used.

\subsection{Modifications of global DNA methylation levels}

To determine a potential effect of parental diuron-exposure on the epigenome, we measured global DNA methylation levels by HPLC (Armstrong et al., 2011) in genitor whole body tissue, their sperm and their offspring. In genitors from Exp1, there were no differences in the global DNA methylation levels among all three exposure groups $(p=0.22)$. The mean percentage of global DNA methylation levels was $1.61 \pm 0.23 \%$ (data not shown). However, significant differences in DNA methylation levels were measured in offspring from the different genitor groups $(p=0.004)$. Spat from genitors exposed either to acetonitrile or to diuron had higher methylation levels compared with the SW control $(1.90 \pm 0.10, p=0.005 ; 1.82 \pm 0.07, p=0.034$ for S1 and D, respectively, versus $1.57 \pm 0.06$ for SW) (Fig. $3 A)$.

In Exp2, we demonstrated a significantly higher DNA methylation level in sperm from diuron-exposed genitors (1.91 $\pm 0.06, p=0.039)$ compared with the seawater control $(1.73 \pm 0.03)$ (Fig. 3B). In addition, differences in DNA methylation levels were also detected in the spat. Spat from diuron-exposed genitors displayed a higher level ( $2.33 \pm$ $0.07, \mathrm{p}=0.002$ ) compared with the seawater group

$(2.03 \pm 0.05)$. In contrast to the effect of acetonitrile in Exp1, parental exposure to DMSO did not appear to have an effect on global DNA methylation levels in offspring ( $2.16 \pm 0.05, p=0.258)$ (Fig. 3C).

\subsection{Effect of parental exposure on spat fitness: growth and survival rates}


In Exp1, the effect of parental diuron-exposure on spat growth was monitored over 20 months. At 3-months of age, spat from diuronexposed genitors displayed a significantly lower wet weight $(0.8 \mathrm{~g} \pm 0.4, \mathrm{p}<0.01)$, shell length $(20.2$ $\mathrm{mm} \pm 3.8, \mathrm{p}<0.001)$ and width $(15.5 \mathrm{~mm} \pm 3.1, \mathrm{p}<0.05)$ compared with the control group $(1.0 \mathrm{~g} \pm 0.4$ and $1.0 \mathrm{~g} \pm 0.3$ for wet weight, $22.9 \mathrm{~mm} \pm 3.4$ and $23.5 \mathrm{~mm} \pm 3.2$ for shell length and $16.6 \mathrm{~mm} \pm 2.8$ and $16.4 \mathrm{~mm} \pm 2.2$ for shell width in SW and S1, respectively) (Table S6). At 6 months, the negative effect was still observed, but only for the shell width for both the parental solvent- and diuron-exposure groups compared with SW $(28.7 \mathrm{~mm} \pm 4.7,28.9 \mathrm{~mm} \pm 4.1$ and $31.0 \mathrm{~mm} \pm 5.0$ for $D, S 1$ and $S W$, respectively) $(p<0.05)$. These differences in growth were no longer observed when the spat reached 8-months of age (Table S6). Field survival was monitored from December 2012 to August 2013 at two culture sites from Marennes-Oléron Bay, La Floride and Agnas (Table S7). The mortality outbreak began in May 2013, with higher mortality at La Floride than Agnas. Indeed, the survival rate was approximately $97 \%$ for all exposure groups at Agnas, whereas at La Floride, the survival rate was $91.3 \%, 87.8 \%$ and $82 \%$ for spat issued from seawater control, solvent- and diuron-exposed genitors, respectively. At the end of the survey, there were no significant differences in survival rates at both sites among the three spat groups $(p>0.05)$, with final survival rates ranging from $64.7 \%$ to $70.3 \%$ (Table S7).

In Exp2, unlike Exp1, no significant differences in spat growth were observed during the first 5 months after hatching among the three exposure groups (Table S6). In Thau Lagoon, from October 2014 to June 2015, significant differences in survival rates of $70.1 \%, 57.2 \%$ and $43.0 \%$ were observed for spat issued from the seawater control, DMSOand diuron-exposed groups, respectively $(p<0.001)$. However, in September 2015, a shift in spat survival was observed, with a higher survival rate of spat from the solvent- $(43.3 \%)$ and diuron-exposed (36.2\%) groups compared with the seawater control group (27.8\%) (Fig. 4, Table S7). In Bourgneuf Bay, from November 2014 to October 2015, the survival rate was always higher for spat from the seawater and solvent-exposure groups than from the diuronexposure group. Significant differences in final survival $(p<0.01$ ) were observed, with rates of $66.3 \%, 63.6 \%$ and $53.0 \%$ for spat issued from the seawater control, solvent- and diuron-exposed genitors, respectively (Fig. 4, Table S7).

\section{Discussion}

In the context of a changing world under increasing anthropogenic pressure, monitoring the impact of contaminants in coastal environment and predicting their long-term effects on individuals and populations is a central point (Reid and Whitehead, 2016). The multi- and transgenerational consequences of contaminant exposures on aquatic organisms have recently became an intensive area of investigations, highlighting in particular epigenetic modifications (Baccarelli and Bollati, 2009; Schwindt, 2015; Vandegehuchte et al., 2010). To date, most toxicological studies have reported direct effects of single contaminants, such as sublethal and acute toxicity and alterations of reproductive, biological or genomic processes and functions, on various model species and aquatic organisms (Altenburger et al., 2012; Hylland et al., 2015; Kim et al., 2015), including the oyster Crassostrea gigas (Akcha et al., 2016; Mottier et al., 2015). Here, we explored in C. gigas the effect of a parental exposure to diuron, an herbicide found in marine coastal environments. We showed that transient exposures of genitors to diuron at environmental concentrations (from 0.2 to $0.48 \mu \mathrm{L} / \mathrm{L}$ ) during gametogenesis produced changes in offspring, namely alterations in transcriptomic profiles, increased global DNA methylation levels and reduced rates of growth and survival during the first year of life. We also demonstrated that the two solvent vehicles tested during this study and commonly used for toxicology studies of hydrophobic substances had significant effect on some of the endpoints measured.

One of the main objectives was to look, in the case of diuron, for genes or gene expression signature as potential biomarkers of parental chemical-exposure, as proposed in the risk assessment for detecting contaminant exposures, quantifying their impact and further evaluating health outcomes (Hylland et al., 2015; Milan et al., 2015). In a first experiment, our approach consisted of RNAseq pre-discovery of target genes (70 genes) that were differentially 
expressed among all three spat groups (from diuron-, solvent-exposed genitors and control seawater) and their screening by high-throughput microfluidic qPCR. Because C. gigas displays an extraordinary interindividual polymorphism in basal gene expression (Rosa et al., 2012), qPCR analyses performed at the individual level strengthened the identification of genes with expression profiles that were significantly altered following parental exposure conditions. Among those genes, 11 genes were found highly specific for the parental-exposure to diuron at $0.3 \mu \mathrm{g} / \mathrm{L}$, a much lower concentration than those reported to be toxic in various aquatic organisms from protozoans to vertebrates (Giacomazzi and Cochet, 2004). However, acetonitrile, which was used as a solvent vehicle, was also shown to alter the expression of 6 genes in a specific manner. It is noteworthy that our transcriptomic study demonstrated that, despite its recommendation for aquatic toxicity testing (OECD, 2000), acetonitrile at concentration as low as $\mathbf{0 . 0 0 5 \%}$ was not neutral even in the case of indirect exposure conditions. In fact, the great diversity of the observed expression profiles revealed combined effects of diuron with its solvent, which were mainly antagonistic effects. The main effect of parental diuron-exposure was illustrated by gene overexpression, whereas parental acetonitrile-exposure had an underexpression effect. It is likely that the effects that were considered as specific to diuron may in fact result from complex interactions between both chemicals.

To assess the specificity and accuracy of the diuron-specific gene expression profiles, we analyzed the set of 96 genes in spat produced in another exposure experiment similar to Exp1, replacing acetonitrile with DMSO (50 $\mu \mathrm{L} / \mathrm{L})$ as the solvent and increasing the effective diuron concentration up to $0.48 \mu \mathrm{g} / \mathrm{L}$ for genitor exposures. Striking differences were observed in the gene expression profiles between the two independent experiments, and the signature that was previously identified in Exp1 as specific for parental diuron-exposure was not validated. Same genes were found to be specific for diuron-exposure in Exp1 and Exp2, but they displayed opposite patterns of expression (upregulated versus downregulated) between both experiments. Thus, diuron-exposure effect appeared to be no gene-specific rather depending on the solvent vehicle used. As for acetonitrile, we demonstrated strong effects of parental DMSO-exposure although the solvent concentration was lower than the $100 \mu \mathrm{L} / \mathrm{L}$ generally recommended by the OECD for biological assays (OECD, 2000). In this respect, the transcriptomic approach has been highly efficient for detecting alterations resulting from parental-exposure to environmental concentrations of contaminants. Changes in transcriptome were hence detected in organisms that were not directly exposed to the herbicide and those parents were exposed to environmentally realistic concentrations. Our study also revealed striking effects of common vehicle solvents even when used at much lower concentrations than those recognized to be toxic by the OECD (2000). Furthermore, our results highlighted the difficulty for monitoring or predicting, at the transcriptomic level, the specific impact of diuron, or other hydrophobic contaminants, due to confounding effects of the vehicle solvent used in the experiments. This point can be extended to (i) the particular case of toxicity study as pesticides are generally used as commercial formulations made of complex mixture of components including dispersants and/or solvents, (ii) the reality of environmental contamination that consists of complex mixtures of diverse pollutants with possible interactive toxic effects.

Surprisingly, the extreme case of alterations demonstrated herein through the transcriptomic analyses was the lack of detection of basal gene expression for several target genes. This phenomenon was already observed in $\mathrm{C}$. gigas in previous high-throughput qPCR work where the basal level of expression of genes involved in immune response could not be detected in some individuals (Rosa et al., 2012). Interestingly, we further demonstrated that the absence of expression of genes coding for a family of antimicrobial peptides was related to the phenomenon of Presence/Absence gene Variability (PAV), the extreme form of gene Copy Number Variation (Rosa et al., 2015). Here, in other respect, as $\mathrm{C}$. gigas genome is highly polymorphic, it cannot be ruled out that only transcripts encoded by particular alleles could have been amplified in our qPCR analyses. The absence of expression appeared to be increased in offspring from parental exposure to solvents, with a more striking effect of DMSO compared with acetonitrile. It is 
likely that the absence of gene expression resulted from mutations or genetic damages that were vertically transmitted to offspring. Such damages have been already demonstrated in offspring from herbicide-exposed oysters such as DNA breakage (Barranger et al., 2014) or loss of chromosomes (Barranger et al., 2015). To date, we cannot exclude the possibility that the absence of expression of some genes indicated also inherited genotoxic impacts that may have further potential consequences on individual adaptation to environmental stressors.

In recent years, pollutant induced-epigenetic effects in living organisms have gained much attention due to their inheritance and their long-term effects on adaptation to stress (Bollati and Baccarelli, 2010; Vandegehuchte and Janssen, 2014). Numerous chemicals, including pesticides, have been found to significantly alter DNA methylation, a major epigenetic mechanism that is particularly critical for development and known to affect gene transcription in various organisms (Collotta et al., 2013). In oyster, several studies have examined DNA methylation, but the potential role of this epigenetic mark on both gene expression and adaptation remains unknown. The basal level of DNA methylation in C. gigas determined by BS-seq (bisulfite sequencing) was approximately 1.8-2.1\% (Gavery and Roberts, 2014), which is similar to the values measured by HPLC-UV in the present study. DNA methylation has been proposed to facilitate transcriptional opportunities and to have a functional role in oyster development with a stagespecific regulatory effect (Rivière, 2014). In the present study, direct exposure of oyster genitors to diuron at environmental concentrations has been shown to affect the expression of the DNMT1 gene (Akcha et al., 2016) but no change in the global DNA methylation level was observed in whole tissues from the individuals analyzed (data not shown). However, we observed a significant increase in the methylation level in F0 male gametes and in the F1 offspring. DNA hypermethylation of exposed genitor sperm was likely transmitted to the next generation as already reported in mammals (Faulk and Dolinoy, 2011). In oyster, the DNA methylation pattern from parents to offspring has been shown to be inherited with few de novo methylation and demethylation events representing less than $6.4 \%$ and $7.1 \%$ of the loci analyzed (Jiang et al., 2015). Because genitors were exposed during gametogenesis, changes in DNA methylation may have occurred in the germ line, a vulnerable and sensitive time point, and then transferred to larvae and spat. Whereas the solvents, either acetonitrile or DMSO, have been shown to alter the spat transcriptome following genitor exposure, only parental exposure to acetonitrile resulted in DNA hypermethylation in offspring. In vertebrates, changes in DNA methylation induced by xenobiotics are correlated to alterations in gene expression (JiménezChillarón et al., 2015). Compared with vertebrate genomes, invertebrate genomes are relatively weakly methylated, and DNA methylation is predominantly found in gene bodies (Zemach et al., 2010). It is noteworthy that the functions of DNA methylation and its potential role in the regulation of gene expression remain unclear, particularly in oyster (Gavery and Roberts, 2014). Poor or an absence of methylation is supposed to facilitate and to increase phenotypic plasticity, an adaptive potential for oysters that live in a highly fluctuating environment (Roberts and Gavery, 2012). Dedicated studies considering the relationship between DNA methylation by BS-seq and expression of the same single genes are requested to get insights into the functional role of methylation in oyster gene expression.

There is now striking evidence in vertebrates that environmental factors increase disease risk at multigenerational and transgenerational levels (Jiménez-Chillarón et al., 2015). To address this question, we monitored the impact of a parental diuron-exposure on oyster fitness, namely growth and survival. The offspring growth appeared to be affected, particularly up through the first 5 or 6 months of life, as well as the survival capacity. It is likely that the most deleterious effects on growth and mortality occurred predominantly in the earlier stages of oyster life. Indeed, parental diuron-exposure was shown to be genotoxic in embryo and larvae due to DNA damage and this kind of damage was associated with delayed hatching, abnormalities in development and reduced larval growth (Barranger et al., 2014).

Thus, our study highlights possible links between genotoxicity and DNA methylation mechanisms. It further provides evidence that one generation of exposure of oyster genitors to diuron results in genome and transcriptome 
alterations together with weakened fitness and survival during the earlier months of offspring life. Importantly, this toxicogenomic study highlights limitations to identifying particular genes or expression signatures that could serve as markers for parental exposure to a specific herbicide pollutant. Indeed, in our experiments, due to confounding effects of the solvent vehicles, diuron randomly affected the oyster genome at the transcriptomic level, thus raising questions regarding the potential development of predictive genomic tools for assessing the impact of hydrophobic contaminants. Regardless, during chronic contaminant exposure, persistent remodeling of the oyster genome may result in reproductive impairment, embryonic abnormalities, growth delay and pre-disposition to diseases, as demonstrated herein in the case of a parental exposure.

\section{Acknowledgments}

This work was funded by the French National Research Agency (Grant ANR-CESA-01601) and the French Institute for Sea Exploration (Ifremer). We warmly acknowledge Rafael Da Rosa for valuable critiques of this work and manuscript, and Adeline Perignon, Erika Gervasoni and Hubert Palvadeau for their technical assistance with the oyster survival experiment in Thau Lagoon and Bourgneuf Bay. 


\section{References}

Akcha, F., Barranger, A., Bachère, E., Berthelin, C.H., Piquemal, D., Alonso, P., Sallan, R.R., Dimastrogiovanni, G., Porte, C., Menard, D., Szczybelski, A., Benabdelmouna, A., Auffret, M., Rouxel, J., Burgeot, T., 2016. Effects of an environmentally relevant concentration of diuron on oyster genitors during gametogenesis: responses of early molecular and cellular markers and physiological impacts. Environ. Sci. Pollut. Res. 23, 8008-8020.

Altenburger, R., Scholz, S., Schmitt-Jansen, M., Busch, W., Escher, B.I., 2012. Mixture toxicity revisited from a toxicogenomic perspective. Environ. Sci. Technol. 46, 2508-2522. http://dx.doi.org/10.1021/es2038036.

Armstrong, K.M., Bermingham, E.N., Bassett, S.A., Treloar, B.P., Roy, N.C., Barnett, M.P.G., 2011. Global DNA methylation measurement by HPLC using low amounts of DNA. Biotechnol. J. 6, $113-117$. http://dx.doi.org/10.1002/biot.201000267.

Baccarelli, A., Bollati, V., 2009. Epigenetics and environmental chemicals. Curr. Opin. Pediatr. 21, $243-251$. http://dx.doi.org/10.1097/MOP.0b013e32832925cc.

Bahamonde, P.A., Feswick, A., Isaacs, M.A., Munkittrick, K.R., Martyniuk, C.J., 2016. Defining the role of omics in assessing ecosystem health: perspectives from the Canadian environmental monitoring program. Environ. Toxicol. Chem. 35, 20-35. http://dx.doi.org/10.1002/etc.3218.

Barranger, A., Akcha, F., Rouxel, J., Brizard, R., Maurouard, E., Pallud, M., Menard, D., Tapie, N., Budzinski, H., Burgeot, T., Benabdelmouna, A., 2014. Study of genetic damage in the Japanese oyster induced by an environmentallyrelevant exposure to diuron: evidence of vertical transmission of DNA damage. Aquat. Toxicol. 146, 93-104. http://dx.doi.org/10.1016/j.aquatox.2013.10.032.

Barranger, A., Benabdelmouna, A., Dégremont, L., Burgeot, T., Akcha, F., 2015. Parental exposure to environmental concentrations of diuron leads to aneuploidy in embryos of the Pacific oyster, as evidenced by fluorescent in situ hybridization. Aquat. Toxicol. 159, 36-43. http://dx.doi.org/10.1016/j.aquatox.2014.11.011.

Bollati, V., Baccarelli, A., 2010. Environmental epigenetics. Heredity (Edinb). 105, pp. 105-112.

Caquet, T., Roucaute, M., Mazzella, N., Delmas, F., Madigou, C., Farcy, E., Burgeot, T.,

Allenou, J.P., Gabellec, R., 2013. Risk assessment of herbicides and booster biocides along estuarine continuums in the Bay of Vilaine area (Brittany, France). Environ. Sci. Pollut. Res. 20, 651-666. http://dx.doi.org/10.1007/s11356012-1171-y.

Collotta, M., Bertazzi, P.A., Bollati, V., 2013. Epigenetics and pesticides. Toxicology 307, 35-41. http://dx.doi.org/10.1016/j.tox.2013.01.017.

Faulk, C., Dolinoy, D.C., 2011. Timing is everything: the when and how of environmentally induced changes in the epigenome of animals. Epigenetics 6, 791-797. http://dx.doi.org/10.4161/epi.6.7.16209.

Gavery, M.R., Roberts, S.B., 2014. A context dependent role for DNA methylation in bivalves. Brief. Funct. Genom. 13, 217-222. http://dx.doi.org/10.1093/bfgp/elt054.

Giacomazzi, S., Cochet, N., 2004. Environmental impact of diuron transformation: a review. Chemosphere 56, 10211032. http://dx.doi.org/10.1016/j.chemosphere. 2004.04.061.

Harvell, C.D., 1999. Emerging marine diseases-climate links and anthropogenic factors. Science 80 (285), $1505-1510$. http://dx.doi.org/10.1126/science.285.5433.1505.

Hylland, K., Burgeot, T., Martínez-Gómez, C., Lang, T., Robinson, C.D., Svavarsson, J., Thain, J.E., Vethaak, A.D., Gubbins, M.J., 2015. How can we quantify impacts of contaminants in marine ecosystems? The ICON project. Mar. Environ. Res. 1-9. http://dx.doi.org/10.1016/j.marenvres.2015.11.006.

Jang, J.S., Simon, V., Feddersen, R.M., Rakhshan, F., Schultz, D., Zschunke, M., Lingle, W.L., Kolbert, C.P., Jen, J., 2011. Quantitative miRNA expression analysis using fluidigm microfluidics dynamic arrays. BMC Genom. 12, 144.

Jiang, Q., Li, Q., Yu, H., Kong, L., 2015. Inheritance and variation of genomic DNA methylation in diploid and Triploid Pacific oyster (Crassostrea gigas). Mar.

Biotechnol. (NY) 124-132. http://dx.doi.org/10.1007/s10126-015-9674-4. 
Jiménez-Chillarón, J.C., Nijland, M.J., Ascensão, A.A., Sardão, V.A., Magalhães, J., Hitchler, M.J., Domann, F.E., Oliveira, P.J., 2015. Back to the future: transgenerational transmission of xenobiotic-induced epigenetic remodeling. Epigenetics 10, 259-273. http://dx.doi.org/10.1080/15592294.2015.1020267.

Kim, H.J., Koedrith, P., Seo, Y.R., 2015. Ecotoxicogenomic approaches for understanding molecular mechanisms of environmental chemical toxicity using aquatic invertebrate, Daphnia model organism. Int. J. Mol. Sci. 16, 1226112287. http://dx. doi.org/10.3390/ijms160612261.

Livak, K.J., Schmittgen, T.D., 2001. Analysis of relative gene expression data using realtime quantitative PCR and the 2(-Delta Delta C(T)) Method. Methods 25, 402-408. http://dx.doi.org/10.1006/meth.2001.1262.

Milan, M., Pauletto, M., Boffo, L., Carrer, C., Sorrentino, F., Ferrari, G., Pavan, L., Patarnello, T., Bargelloni, L., 2015. Transcriptomic resources for environmental risk assessment: a case study in the Venice lagoon. Environ. Pollut. 197, 90-98. http://dx. doi.org/10.1016/j.envpol.2014.12.005.

Mottier, A., Séguin, A., Devos, A., Pabic, C., Le, Voiseux, C., Lebel, J.M., Serpentini, A., Fievet, B., Costil, K., 2015. Effects of subchronic exposure to glyphosate in juvenile oysters (Crassostrea gigas): from molecular to individual levels. Mar. Pollut. Bull. 95, 665-677. http://dx.doi.org/10.1016/j.marpolbul.2014.10.026.

OECD, 2000. Guidance document on aquatic toxicity testing of difficult substances and mixtures. Environ. Heal. Saf. Publ. Ser. Test. Assess. - N²3 53. doi:ENV/JM/MONO) (2007)(10).

Petton, B., Bruto, M., James, A., Labreuche, Y., Alunno-Bruscia, M., Le Roux, F., 2015. Crassostrea gigas mortality in France: the usual suspect, a herpes virus, may not be the killer in this polymicrobial opportunistic disease. Front. Microbiol. 6, 686. http:// dx.doi.org/10.3389/fmicb.2015.00686.

Reid, N.M., Whitehead, A., 2016. Functional genomics to assess biological responses to marine pollution at physiological and evolutionary timescales: toward a vision of predictive ecotoxicology. Brief. Funct. Genom. 15, 358-364. http://dx.doi.org/10. 1093/bfgp/elv060.

Rivetti, I., Fraschetti, S., Lionello, P., Zambianchi, E., Boero, F., 2014. Global warming and mass mortalities of benthic invertebrates in the Mediterranean Sea. PLoS One 9, 1-22. http://dx.doi.org/10.1371/journal.pone.0115655.

Rivière, G., 2014. Epigenetic features in the oyster Crassostrea gigas suggestive of functionally relevant promoter DNA methylation in invertebrates. Front. Physiol (5 APR).

Roberts, S.B., Gavery, M.R., 2012. Is there a relationship between DNA methylation and phenotypic plasticity in invertebrates? Front. Physiol (2 JAN).

Rosa, R.D., de Lorgeril, J., Tailliez, P., Bruno, R., Piquemal, D., Bachère, E., 2012. A hemocyte gene expression signature correlated with predictive capacity of oysters to survive Vibrio infections. BMC Genom. 13, 252. http://dx.doi.org/10.1186/14712164-13-252.

Rosa, R.D., Alonso, P., Santini, A., Vergnes, A., Bachère, E., 2015. High polymorphism in big defensin gene expression reveals presence-absence gene variability (PAV) in the oyster Crassostrea gigas. Dev. Comp. Immunol. 49, 231238. http://dx.doi.org/10. 1016/j.dci.2014.12.002.

Schwindt, A.R., 2015. Parental effects of endocrine disrupting compounds in aquatic wildlife: is there evidence of transgenerational inheritance? Gen. Comp. Endocrinol. 219, 152-164. http://dx.doi.org/10.1016/j.ygcen.2015.01.020.

Segarra, A., Mauduit, F., Faury, N., Trancart, S., Dégremont, L., Tourbiez, D., Haffner, P., Barbosa-Solomieu, V., Pépin, J.-F., Travers, M.-A., Renault, T., 2014. Dual transcriptomics of virus-host interactions: comparing two Pacific oyster families presenting contrasted susceptibility to ostreid herpesvirus 1. BMC Genom. 15, 580. http://dx.doi.org/10.1186/1471-2164-15-580.

Soler, M.-J., 2014. Recensement de la conchyliculture 2012. Agreste Primeur 1-6.

Thorvaldsdóttir, H., Robinson, J.T., Mesirov, J.P., 2013. Integrative Genomics Viewer (IGV): high-performance Genomics data visualization and exploration. Brief. Bioinform. 14, $178-192$. http://dx.doi.org/10.1093/bib/bbs017. 
Trapnell, C., Roberts, A., Goff, L., Pertea, G., Kim, D., Kelley, D.R., Pimentel, H., Salzberg, S.L., Rinn, J.L., Pachter, L., 2012. Differential gene and transcript expression analysis of RNA-seq experiments with TopHat and Cufflinks. Nat. Protoc. 7, 562-578.

Vandegehuchte, M.B., Janssen, C.R., 2014. Epigenetics in an ecotoxicological context. Mutat. Res. - Genet. Toxicol. Environ. Mutagen. 764-765, 36-45. http://dx.doi.org/ 10.1016/j.mrgentox.2013.08.008.

Vandegehuchte, M.B., Vandenbrouck, T., De Coninck, D., De Coen, W.M., Janssen, C.R., 2010. Gene transcription and higher-level effects of multigenerational Zn exposure in Daphnia magna. Chemosphere 80, 1014-1020. http://dx.doi.org/10.1016/j. chemosphere.2010.05.032.

Vandesompele, J., De Preter, K., Pattyn, F., Poppe, B., Van Roy, N., De Paepe, A., Speleman, F., 2002. Accurate normalization of real-time quantitative RT-PCR data by geometric averaging of multiple internal control genes. Genome Biol. 3 (research0034.1-0034.11).

Zemach, A., McDaniel, I.E., Silva, P., Zilberman, D., 2010. Genome-wide evolutionary analysis of eukaryotic DNA methylation. Science 80 (328), 916-919.

Zhang, G., Fang, X., Guo, X., Li, L., Luo, R., Xu, F., Yang, P., Zhang, L., Wang, X., Qi, H., Xiong, Z., Que, H., Xie, Y., Holland, P.W.H., Paps, J., Zhu, Y., Wu, F., Chen, Y., Wang, J.J.J.J.J., Peng, C., Meng, J., Yang, L., Liu, J., Wen, B., Zhang, N., Huang, Z., Zhu, Q., Feng, Y., Mount, A., Hedgecock, D., Xu, Z., Liu, Y., Domazet-Lošo, T., Du, Y., Sun, X., Zhang, S.S., Liu, B., Cheng, P., Jiang, X., Li, J., Fan, D., Wang, W., Fu, W., Wang, T., Wang, B., Zhang, J., Peng, Z., Li, Y.Y., Li, N.N., Wang, J.J.J.J.J., Chen, M., He, Y., Tan, F., Song, X., Zheng, Q., Huang, R., Yang, H.H., Du, X., Chen, L., Yang, M., Gaffney, P.M., Wang, S., Luo, L., She, Z., Ming, Y., Huang, W., Zhang, S.S., Huang, B., Zhang, Y., Qu, T., Ni, P., Miao, G., Wang, J.J.J.J.J., Wang, Q., Steinberg, C.E.W., Wang, H., Li, N.N., Qian, L., Zhang, G.G., Li, Y.Y., Yang, H.H., Liu, X., Wang, J., Yin, Y., Wang, J., 2012. The oyster genome reveals stress adaptation and complexity of shell formation. Nature 490, 49-54. http://dx.doi.org/10.1038/nature11413. 


\section{Figure 1}

Venn diagram representing the differentially expressed genes in experiment 1 (A) and experiment 2 (B). Genes overexpressed and underexpressed in oyster spat issued from parental exposure to Diuron (D) or to solvents, S1 acetonitrile and S2 DMSO compared to control spat. (http://bioinfogp.cnb.csic.es/tools/venny/index.html).
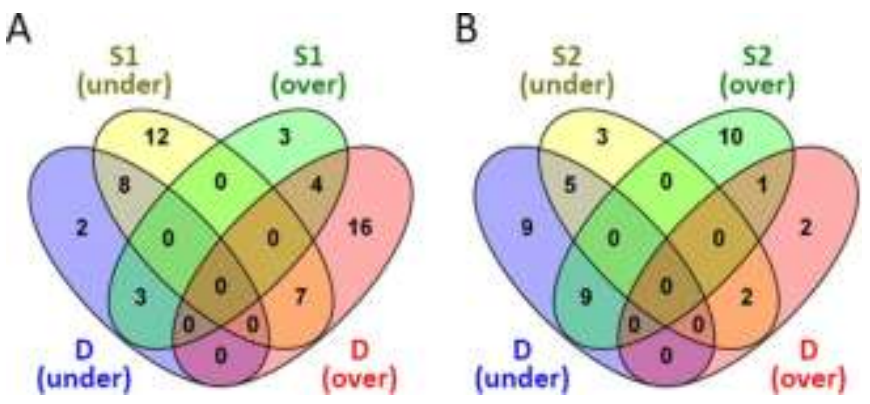


\section{Figure 2}

Examples of various effects of parental exposure on gene expression in the spat from Exp1 (A) and Exp2 (B). Gene expression profiles characteristic of the specific effects of diuron and of the solvents, acetonitrile or DMSO, and characteristic of the antagonistic effects of diuron and its solvent.

\section{A - Experiment 1}

Specific effect of Diuron (in acetonitrile solvent)
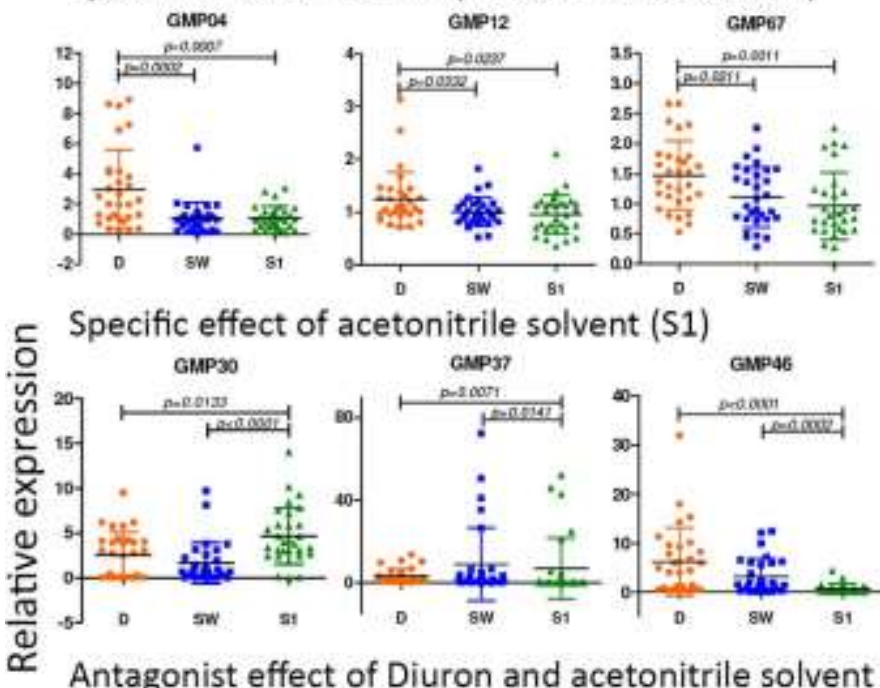

\section{B - Experiment 2}

Specific effect of Diuron (in DMSO)

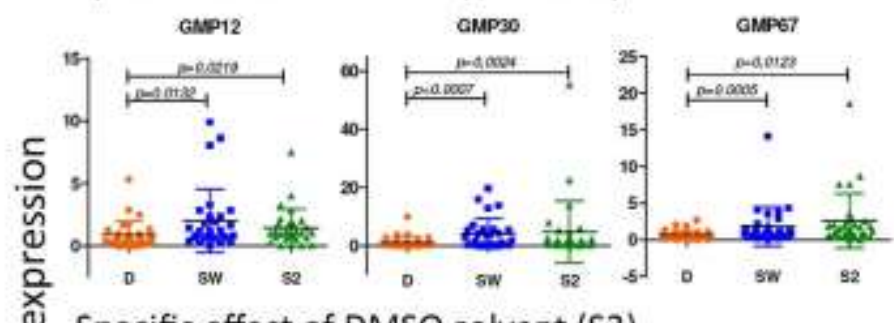

Specific effect of DMSO solvent (S2)

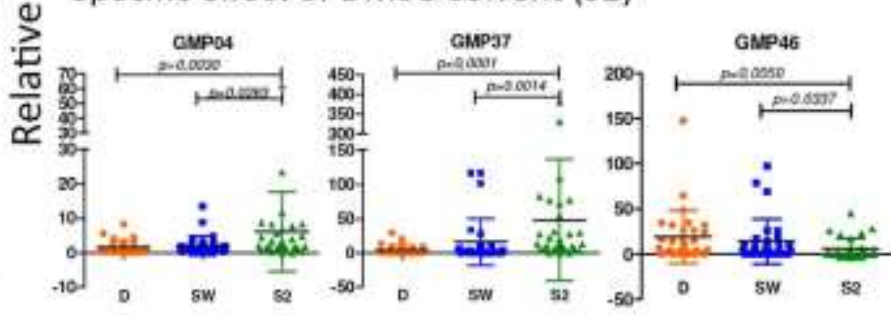

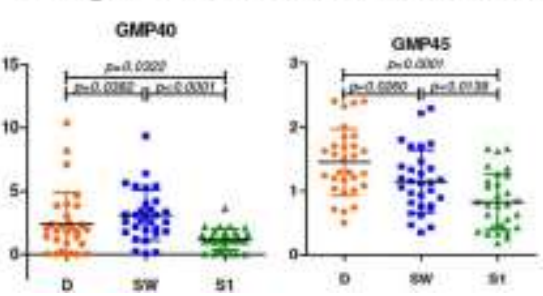




\section{Figure 3}

Global DNA methylation levels measured in Exp1 (A) in spat issued from control seawater (SW), acetonitrileexposed (S1) and diuron-exposed (D) genitors; in Exp2, (B) in sperm and (C) spat issued from control seawater (SW), DMSO-exposed (S2) and diuron-exposed genitors. One-way ANOVA followed by Tukey's multiple comparison posthoc test. Data with different letters are significantly different $(p<0.05)$. . Mean; $\square$ Mean $\pm S E ;$ I Mean $\pm 95 \%$ conf. interval.
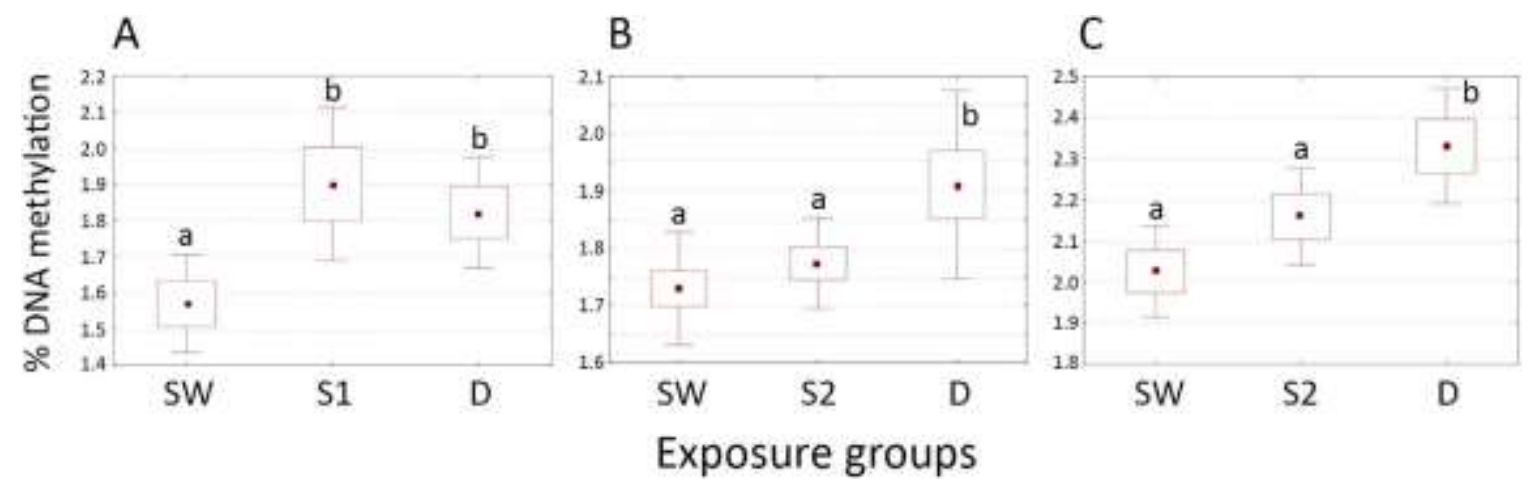


\section{Figure 4}

Kaplan-Meier survival curves generated for spat from Exp2 issued from control seawater (SW), DMSO-exposed and diuron-exposed (D) genitors, after one year-cultivation in Bourgneuf Bay (Marennes-Oléron) and Thau Lagoon (Mediterranean coast). Asterisks indicate significant differences in survival between exposure groups. $(* *) p<0.01$ and $(* * *) p<0.001$.

\section{Survival in Bourgneuf}

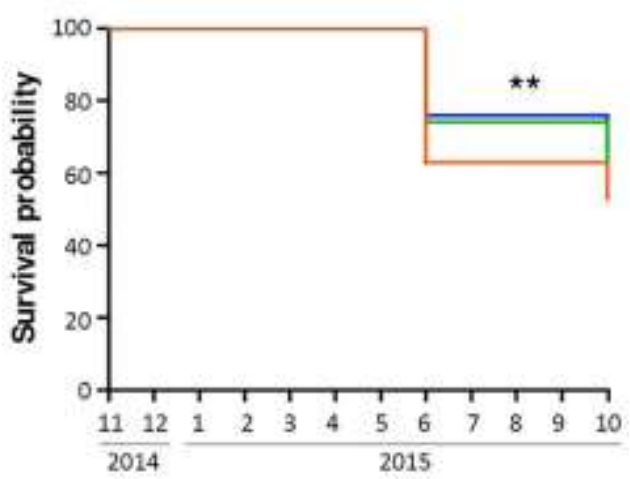

Survival in Thau Lagoon

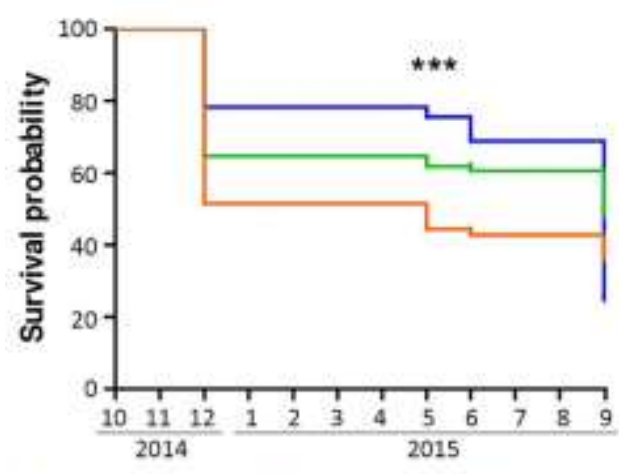

$\rightarrow$ Seawater $\rightarrow$ DMSO $\rightarrow$ Diuron 